\title{
Water mass transport through the northern Bashi Channel in the northeastern South China Sea affects copepod assemblages of the Luzon Strait
}

Wen-Tseng Lo', Hans-Uwe Dahms ${ }^{1,2}$ and Jiang-Shiou Hwang ${ }^{3^{*}}$

\begin{abstract}
Background: It is controversial to what extent the intrusion of the Kuroshio Branch Current to the Luzon Strait and the South China Sea circulation can shape copepod assemblages around southern Taiwan. We tested the hypothesis that currents such as the Kuroshio Current bring marine zooplankton and copepods from subtropical and tropical waters to the south of Taiwan. We studied copepod assemblages from the Bashi Channel in the northeastern South China Sea at the coast of southwest Taiwan during early October 1996.

Results: A total of 77 copepod species were identified from 34 genera that included calanoids, cyclopoids, harpacticoids, and poecilostomatoids. Several indicator species suggest that the study area is highly influenced by water masses from the northern South China Sea as well as from the Kuroshio Current. Acrocalanus gracilis (Paracalanidae, Calanoida) was most abundant (with a relative abundance (RA) of 22.07 and an occurrence rate (OR) of 100\%), followed by Paracalanus aculeatus (Paracalanidae, Calanoida) and Oncaea venusta (Cyclopoida). The stations close to the Kuroshio Current showed a higher species diversity $(\mathrm{H})$ and a higher species richness with 3.9 to 4.6 at moderate abundance, whereas station 11 showed lowest species diversity $\left(H^{\prime}\right)$ with (2.1), accompanied by the far lowest species number (14) and abundance (880 ind./100 $\mathrm{m}^{3}$ ).
\end{abstract}

Conclusions: Several indicator species suggest that the study area is highly influenced by water masses from the northern South China Sea as well as from the Kuroshio Current.

Keywords: Marine plankton; Community ecology; Copepoda; Current regimes; Kuroshio Branch Current; Bashi Channel

\section{Background}

The complexity of oceanic circulations around the island of Taiwan generated a high diversity of marine life, comprising about $10 \%$ of the world's total marine fauna and including a large number of endemic species. Such high diversity is suggested to be enhanced by ocean currents and water movements that also affect the structure of copepod communities at spatial and temporal scales. Along the Taiwan Strait and the southern edge of the East China Sea, water circulations are strongly influenced by monsoon winds. During the NE monsoon period in winter (September to April), the China Coastal Current brings cold water from the Yellow Sea and from the East China

\footnotetext{
* Correspondence: Jshwang@mail.ntou.edu.tw

${ }^{3}$ Institute of Marine Biology, National Taiwan Ocean University, Keelung 202, Taiwan

Full list of author information is available at the end of the article
}

Sea to the Taiwan Strait (Liu et al. 2003; Tseng and Shen 2003; Hwang and Wong 2005; Hwang et al. 2006; Chang et al. 2010).

Water circulation in this area varies seasonally with changes in wind direction. Physical oceanography indicates that the Kuroshio Current intrudes into both the northern South China Sea and the coastal waters of southern Taiwan via the Luzon Channel, particularly during winter (Tseng and Shen 2003). The Luzon Channel is an important water way transporting marine fauna from the Kuroshio Current towards the northeastern South China Sea and the coastal waters of southern Taiwan (Hwang et al. 2006; Hsieh et al. 2011; Hsieh et al. 2012).

The objective of this study was to investigate spatial patterns of copepod biodiversity in the northeastern part of the South China Sea. Based on evidence from previous studies, we tested the following two hypotheses in the 
present paper: (a) are the copepod assemblages characteristic for the northeastern South China Sea? and (b) is the copepod composition in coastal areas of southern Taiwan affected by Luzon Strait waters? We use the data from 15 stations along 3 latitudinal transects in the northern South China Sea to test these questions.

\section{Methods}

The study was conducted on board the Ocean Researcher III during cruise 244 from 1 to 3 October 1996. Data were collected from 15 sampling stations in the northeastern South China Sea to investigate the copepod composition, abundance, and distribution in the Luzon Strait. Locations of the 15 sampling stations are shown in Figure 1.

\section{Zooplankton sampling}

Zooplankton samples were collected on board the Ocean Researcher III along the KC edge, the Luzon Strait, and the NSCS around the southern tip of the island of Taiwan. The map of sampling stations along two main transects is following latitude $21^{\circ} 30^{\prime}\left({ }^{\circ} \mathrm{N}\right)$ and latitude $21^{\circ} 45^{\prime}\left({ }^{\circ} \mathrm{N}\right)$ in the northern South China Sea and the Bashi Channel. At each sampling station, sea surface tows (1 to $5 \mathrm{~m}$ ) were taken using a 4.5-m-long conical zooplankton net with a 1-m mouth diameter (see Dahms and Hwang 2010). Each sample was collected by a zooplankton net towing for 15 to $20 \mathrm{~min}$ with the vessel speed of 2 nautical miles per hour. The water volume filtered was estimated from records of a flow meter that was mounted in the center of the net opening. Zooplankton was preserved in 5\% formalin immediately after collection. In the laboratory, copepod species were counted under a stereomicroscope. We used the Shannon-Wiener index to calculate species diversity of copepods. Sea water temperature and salinity information was obtained from the conductivity-temperature-depth (CTD) instrument before plankton tows were taken.

\section{Identification and enumeration}

In the laboratory, each sample was split with a Folsom splitter to a subsample of less than 500 individuals for taxonomic identification and counting. Species composition of each sample was determined by counting all mature animals in the subsamples. The following keys and taxonomic references were used for copepod identification: Chen and Zhang (1965); Chen et al. (1974); Huys and Boxshall (1992); Chen (1992), and Chihara and Murano (1997). Other monographs were consulted for the identification of particular species (Frost and Fleminger 1968; Nishida 1985; Bradford-Grieve 1994; Markhaseva 1996).

\section{Spatial similarity analysis}

In order to elucidate the relative importance of spatial and temporal scales in this study, we compared the similarity of species composition among stations for each sampling date. It is suggested in the literature that the hydrographic situation of the study area is influenced by the surrounding ocean currents and that water sources

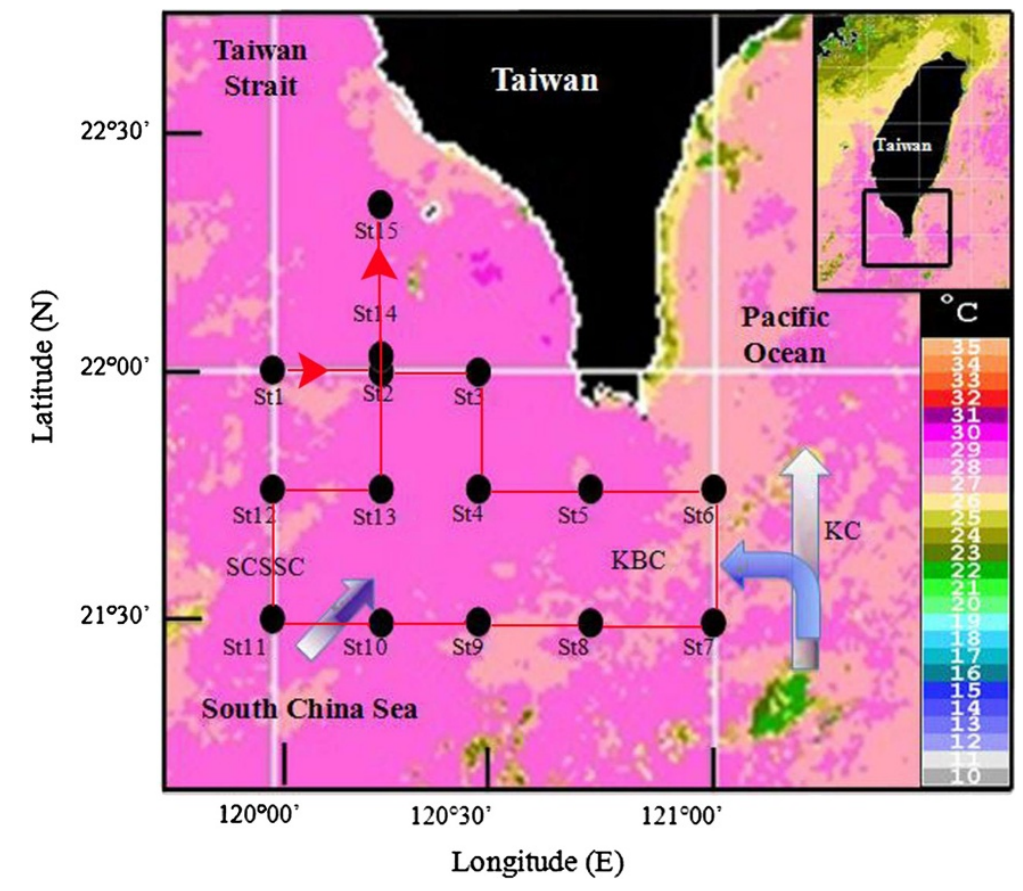

Figure 1 Sampling stations and satellite image of seawater surface temperature in the waters southwest of Taiwan. During the cruise of 1 to 3 October 1996. 
will affect the structure of copepod communities at spatial and temporal scales.

We analyzed copepod community structures between each station by applying the Plymouth Routines In Multivariate Ecology Research (PRIMER) computer package. To compare differences in copepod groups with station samples, the logarithmic abundances of the most common species (those with occurrence rates of $>20 \%$ ) were standardized; then, cluster analysis (CA) was used to place species with similar distributions into groups or clusters using minimum variance (or Ward) linkages. To identify groups of copepod species that covaried in logarithmic abundance, the data matrix was transposed so that samples became variables, and then, cluster analysis was used to determine the covarying species groups. The numerical abundances of all copepod species in each group were integrated and averaged to display their distribution patterns.

\section{Results}

\section{Temperature versus salinity}

Sea surface temperatures to the east and southeast of Taiwan averaged $25^{\circ} \mathrm{C}$ throughout the year due to the influence of the warmer KC and tropical SCS waters. In contrast, surface salinity varied widely among sampling stations and did not show a clear pattern. The characteristic of the T/S diagram in the upper waters at station 1 was between the South China Sea Surface Current and the Kuroshio Current, while deeper zones were influenced by the warmer Kuroshio Current (Figure 2).

\section{Systematic inventory}

Copepods were the most dominant component of the zooplankton in the study area in terms of species richness and numerical abundance. The distribution of copepods was relatively patchy. A total of 77 copepod species were identified from 34 genera that include calanoids, cyclopoids, harpacticoids, and poecilostomatoids (Table 1).

\section{Comparison of stations: copepod abundance, relative abundance, and occurrence}

High copepod abundances in the study area are shown to be caused by both a year-round Kuroshio Current intrusion and the SW monsoon, prevailing in the South China Sea during summer that brings plankton from subtropical and tropical regions. Several indicator species suggest that the study area is highly influenced by water masses from the northern South China Sea as well as from the Kuroshio Current. Among them was Acrocalanus gracilis, the most abundant (with a relative abundance (RA) of 22.07 and an occurrence rate (OR) of 100\%), followed by Paracalanus aculeatus and Oncaea venusta (Table 2). The stations close to the Kuroshio Current showed a higher Shannon-Wiener index as species diversity $\left(\mathrm{H}^{\prime}\right)$ and a higher species richness with 4.0 to 4.3 at a moderate abundance (mean abundance was 14,950 ind./100 $\mathrm{m}^{3}$ ), whereas station 11 showed lowest species diversity (2.1), accompanied by the far lowest species number (14) and abundance ( 880 ind. $/ 100 \mathrm{~m}^{3}$ ).

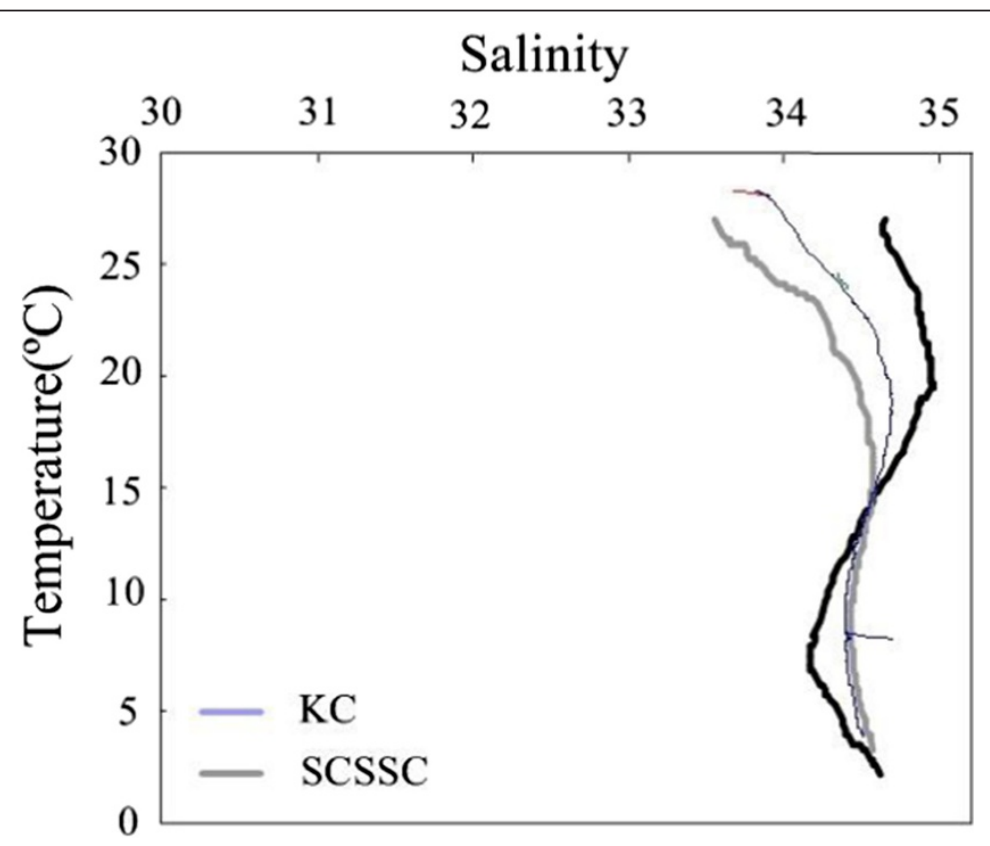

Figure 2 Temperature-salinity diagram from the sampling station 1 in the waters southwest of Taiwan. During the cruise of 1 to 3 October 1996. SCSSC refers to the South China Sea Surface Current and KC to the Kuroshio Current. 
Table 1 List of copepod species from all sampling stations of the present study

CALANOIDA
ACARTIIDAE
Acartia danae Giesbrecht 1889
A. negligens Dana 1849
CALANIDAE
Canthocalanus pauper (Giesbrecht
1888)
Cosmocalanus darwinii (Lubbock
1860)
Nannocalanus minor (Claus 1863)
Neocalanus gracilis (Dana 1849)
Undinula vulgaris (Dana 1849)
CALOCALANIDAE
Calocalanus pavo (Dana 1849)
C. plumulosus (Claus 1863)

\section{CANDACIIDAE}

Candacia catula (Giesbrecht 1892)

C. curta (Dana 1849)

C. pachydactyla (Dana 1849)

Paracandacia truncata Dana 1849

P. simplex (Giesbrecht 1888)

\section{CENTROPAGIDAE}

Centropages calaninus (Dana 1849)

C. furcatus (Dana 1849)

C. gracilis (Dana 1849)

C. orsini Giesbrecht 1889

\section{CLAUSOCALANIDAE}

Clausocalanus furcatus (Brady 1883)

\section{EUCALANIDAE}

Pareucalanus attenuatus (Dana 1849)

Rhincalanus rostrifrons (Dana 1852)

Subeucalanus crassus (Giesbrecht 1888)

Subeucalanus subcrassus

(Giesbrecht 1888)

EUCHAETIDAE

Euchaeta indica Wolfenden 1905

E. rimana Bradford 1974

\section{LUCICUTIIDAE}

Lucicutia flavicornis (Claus 1863)

L. ovalis (Giesbrecht 1889)

Corycaeus (Agestus) flaccus

Pontellopsis strenua (Dana 1849)

L. detruncata (Dana 1849)

L. minuta Giesbrecht 1889

Pontella fera Dana 1849

Pontellina plumata (Dana 1849)

\section{SCOLECITRICHIDAE}

Scolecithricella emarginata (Farran 1905)

Scolecithrix nicobarica Sewell 1929

\section{TEMORIDAE}

Temora discaudata (Giesbrecht 1889)

T. turbinata (Dana 1849)

CYCLOPOIDA

OITHONIDAE

Oithona setigera Dana 1849

O. similis Claus 1866

O. tenuis Rosendorn 1917

HARPACTICOIDA

MIRACIIDAE

Macrosetella gracilis (Dana 1847)

POECILOSTOMATOIDA

\section{CORYCAEIDAE} Giesbrecht 1891

C. (Corycaeus) crassiusculus Dana 1849

C. (C.) speciosus Dana 1849

C. (C.) vitreus Dana 1849

C. (Ditrichocorycaeus) affinis McMurrich 1916

C. (D.) dahli Tanaka 1957

C. (D.) erythraeus Cleve 1901

C. (D.) lubbocki Giesbrecht 1891

C. (D.) subtilis M. Dahl 1912

C. (Monocorycaeus) robustus Giesbrecht 1891

C. (Onychocorycaeus) catus F. Dahl 1894

C. (O.) pacificus M. Dahl 1912

C. (O.) pumilus M. Dahl 1912

C. (Urocorycaeus) lautus Dana 1849

C. (U.) longistylis Dana 1849

Farranula gibbula Giesbrecht 1891
Table 1 List of copepod species from all sampling stations of the present study (Continued)

\begin{tabular}{|c|c|}
\hline METRIDINIDAE & ONCAEIDAE \\
\hline Pleuromamma borealis (Dahl 1893) & Oncaea venusta Philippi, 1843 \\
\hline P. gracilis (Claus 1863) & SAPPHIRINIDAE \\
\hline P. xiphias (Giesbrecht 1889) & Copilia mirabilis Dana 1849 \\
\hline PARACALANIDAE & C. quadrata Dana 1852 \\
\hline Acrocalanus gibber Giesbrecht 1888 & Sapphirina angusta Dana 1849 \\
\hline A. gracilis Giesbrecht 1888 & S. darwini Haeckel 1864 \\
\hline A. monachus Giesbrecht 1888 & S. intestinata Giesbrecht 1891 \\
\hline $\begin{array}{l}\text { Paracalanus aculeatus Giesbrecht } \\
1888\end{array}$ & S. iris Dana 1849 \\
\hline PONTELLIDAE & S. nigromaculata Claus 1849 \\
\hline Calanopia elliptica (Dana 1849) & S. scarlata Giesbrecht 1891 \\
\hline C. minor A. Scott 1902 & S. sinuicauda Brady 1883 \\
\hline Labidocera acuta (Dana 1849) & \\
\hline
\end{tabular}

Table 2 Average abundance, relative abundance, and occurrence of the $\mathbf{2 0}$ most common copepod species in the waters southwest of Taiwan

\begin{tabular}{llll}
\hline Species & Abundance & RA & OR \\
\hline Acrocalanus gracilis & $3,300 \pm 1,215$ & 22.07 & 100 \\
Paracalanus aculeatus & $2,073 \pm 716$ & 13.87 & 93 \\
Oncaea venusta & $1,638 \pm 441$ & 10.96 & 80 \\
Undinula vulgaris & $894 \pm 378$ & 5.98 & 73 \\
Clausocalanus paululus & $787 \pm 262$ & 5.26 & 73 \\
Acartia negligens & $540 \pm 166$ & 3.61 & 87 \\
Farranula gibbula & $423 \pm 120$ & 2.83 & 87 \\
Lucicutia flavicornis & $391 \pm 224$ & 2.62 & 33 \\
Cosmocalanus darwinii & $374 \pm 216$ & 2.50 & 40 \\
Temora discaudata & $354 \pm 118$ & 2.37 & 80 \\
Acrocalanus gibber & $325 \pm 104$ & 2.17 & 73 \\
Clausocalanus furcatus & $306 \pm 100$ & 2.05 & 73 \\
Canthocalanus pauper & $305 \pm 220$ & 2.04 & 53 \\
Eucalanus subcrassus & $253 \pm 91$ & 1.69 & 67 \\
Calanopia elliptica & $203 \pm 60$ & 1.36 & 80 \\
Sapphirina intestinata & $182 \pm 182$ & 1.22 & 7 \\
Corycaeus (D.) erythraeus & $155 \pm 51$ & 1.04 & 67 \\
Calanopia minor & $154 \pm 74$ & 1.03 & 47 \\
Copilia mirabilis & $152 \pm 67$ & 1.02 & 60 \\
Temora turbinata & $146 \pm 108$ & 0.98 & 27 \\
Other copepods (58) & $1,993 \pm 1,034$ & 13.35 & - \\
Total & $14,950 \pm 2,947$ & 100 & - \\
\hline Tawanaver & & & 73 \\
\hline
\end{tabular}

Taiwan average abundance (mean $\pm \mathrm{SE}$, ind./100 $\mathrm{m}^{3}$ ), relative abundance (RA, \%), and occurrence $(\mathrm{OR}, \%)$ of the 20 most common copepod species in the waters southwest of Taiwan during the cruise of 1 to 3 October 1996. 


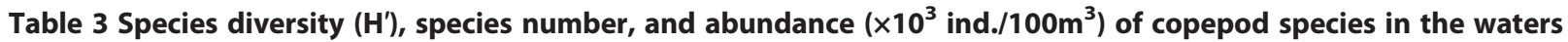
southwest of Taiwan

\begin{tabular}{lllllllllllllllll}
\hline Station & $\mathbf{1}$ & $\mathbf{2}$ & $\mathbf{3}$ & $\mathbf{4}$ & $\mathbf{5}$ & $\mathbf{6}$ & $\mathbf{7}$ & $\mathbf{8}$ & $\mathbf{9}$ & $\mathbf{1 0}$ & $\mathbf{1 1}$ & $\mathbf{1 2}$ & $\mathbf{1 3}$ & $\mathbf{1 4}$ & $\mathbf{1 5}$ & Mean \\
\hline $\mathrm{H}^{\prime}$ & 3.2 & 3.5 & 3.6 & 3.7 & 4.6 & 4.4 & 3.9 & 3.9 & 4.1 & 3.5 & 2.1 & 3.4 & 2.4 & 2.8 & 3.2 & $3.5 \pm 0.2$ \\
Species number & 26 & 28 & 22 & 27 & 43 & 38 & 29 & 30 & 32 & 22 & 14 & 26 & 31 & 22 & 23 & $28 \pm 2$ \\
Abundance & 17.1 & 13.6 & 15.0 & 15.4 & 13.0 & 21.2 & 3.6 & 16.8 & 9.5 & 2.1 & 0.9 & 13.5 & 27.1 & 8.1 & 47.4 & $14.9 \pm 2.9$ \\
\hline
\end{tabular}

During the cruise of 1 to 3 October 1996.

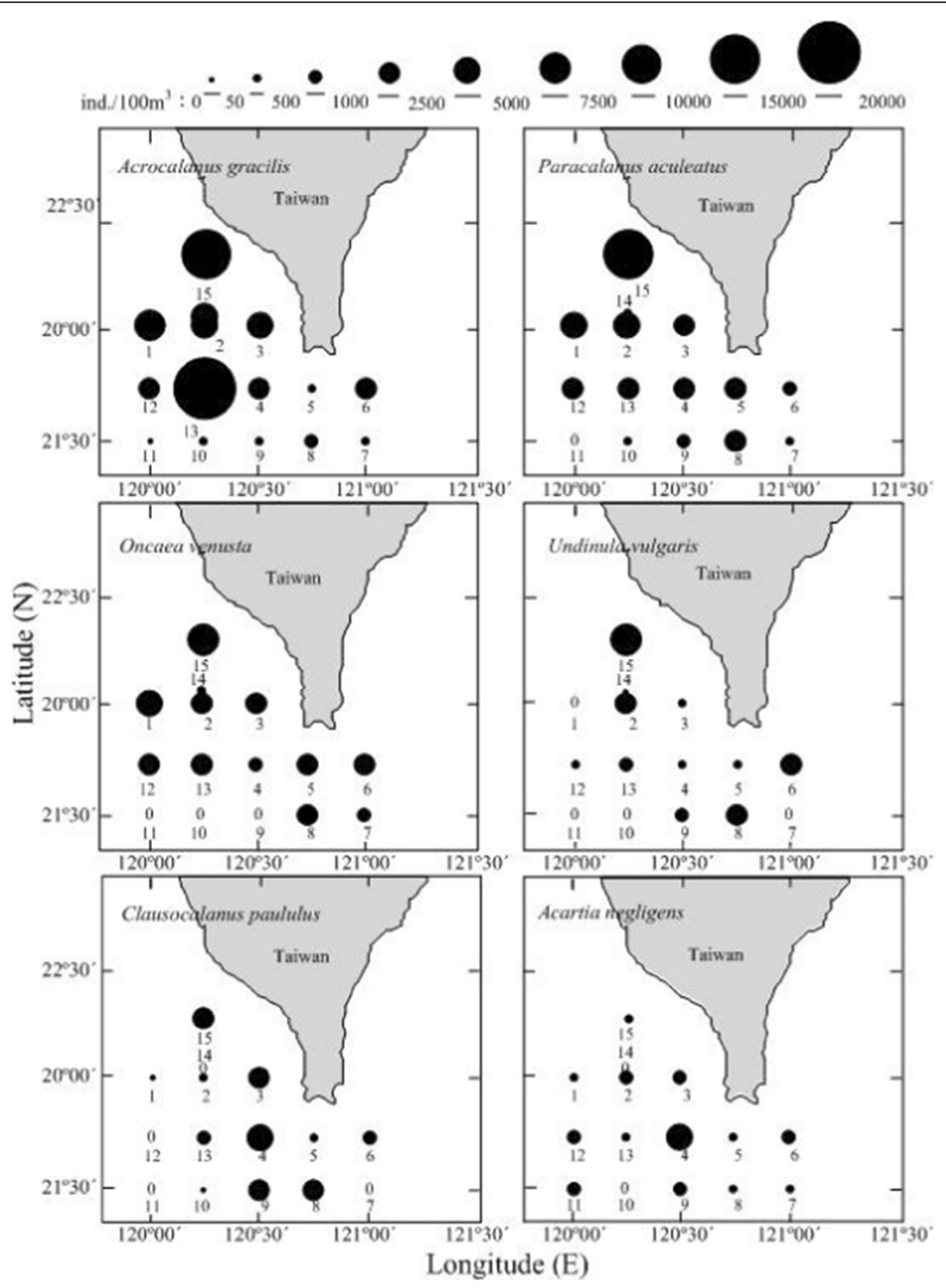

Figure 3 Numerical abundance of the 12 most common copepod species in the waters southwest of Taiwan. During the cruise of 1 to 3 October 1996. 


\section{Spatial similarity analysis}

In order to elucidate the relative importance of spatial and temporal scales in this analysis, we compared the similarity of species composition among stations for each sampling date. It is suggested in the literature that the hydrographic situation of the study area is influenced by the surrounding ocean currents and that water sources will affect the structure of copepod communities at spatial and temporal scales.

The numerical abundance, species number, and ShannonWiener diversity of copepods in the waters southwest of Taiwan during the cruise of 1 to 3 October 1996 are provided in Table 3. The most abundant two species are by far $A$. gracilis and P. aculeatus (Figure 3). Most dominant copepods exhibited higher abundance in the waters closer to the southwestern coast of Taiwan, with the exception of Lucicutia flavicornis, Cosmocalanus darwinii, and Temora discaudata, having higher numbers in the waters near the Kuroshio Current. All dominant copepod species showed lowest abundance in the northeastern South China Sea at station 10 and station 11 (Figure 3).

Four station groups were defined from the results of a cluster analysis using the 48 most dominant copepod species that are delineated on the map (Figure 4): group I contains stations mostly in the northern SCS and KC, group II contains three stations located in the transition zone of the three station groups (coastal waters, Kuroshio Current, and northeastern South China Sea), group III contains two stations in the northeastern South China Sea, and group IV contains five stations in or near the Kuroshio Current.

Four copepod assemblages were also distinguished using covarying copepod species groups and their distribution patterns in the waters southwest of Taiwan during the cruise of 1 to 3 October 1996 (Figure 5). Group I contains stations with the most dominant species with higher abundances in the coastal waters of southwestern Taiwan and lower numbers in the waters near the northern SCS and KC. Group II contains stations in the waters near KC. Group II contains stations characterized by low abundance at all stations during the present study. The species in group IV have higher abundances in the coastal waters of southwestern Taiwan and lower abundances in the waters near the SCSSC and KC, but most species of this group were not dominant.

\section{Discussion}

The zooplankton communities in the boundary waters of the northeastern South China Sea are unique and complex as a result of the collective impacts of these three water circulations (Hwang et al. 1998; Shih and Chiu 1998; Hwang and Wong 2005; Hwang et al. 2006). This notion could be substantiated by our present investigation. According to Shih and Young (1995), there are 431 planktonic copepod species recorded from the marginal seas of China, including the waters surrounding Taiwan. The number of recorded species of planktonic

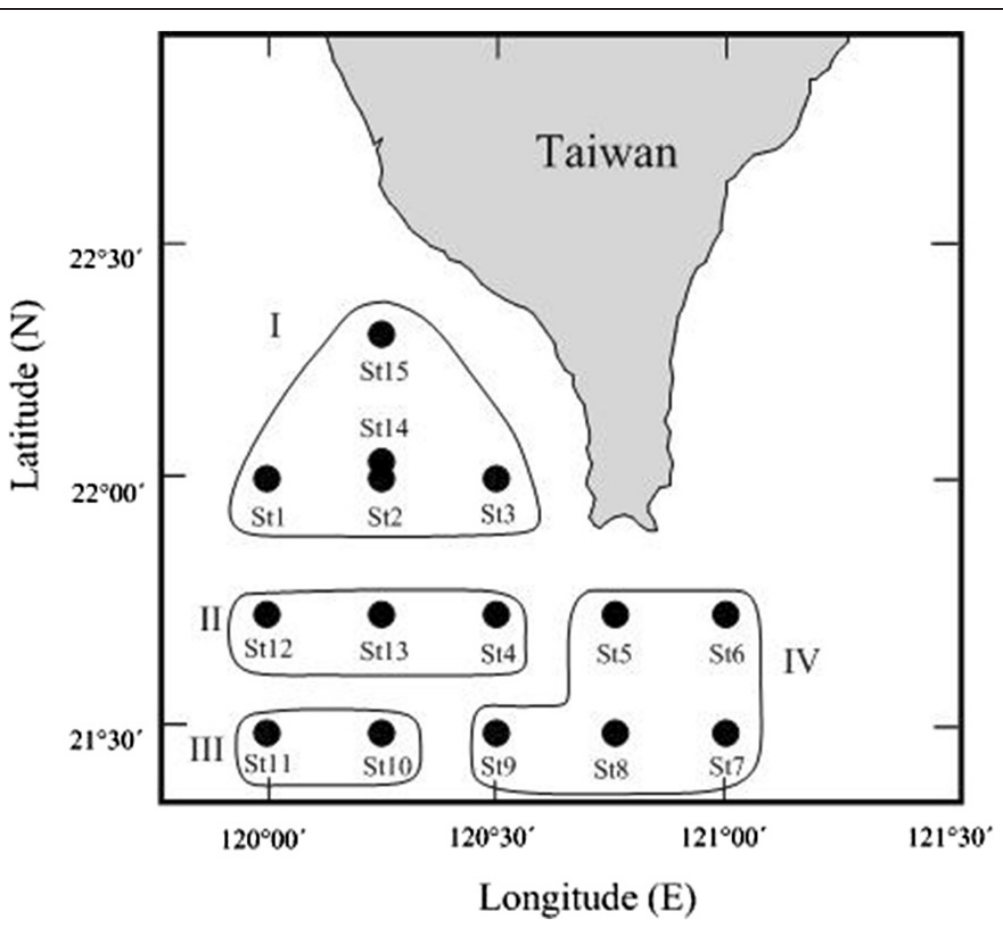

Figure 4 Station groups delineated from the result of cluster analysis using 48 most dominant copepod species. 


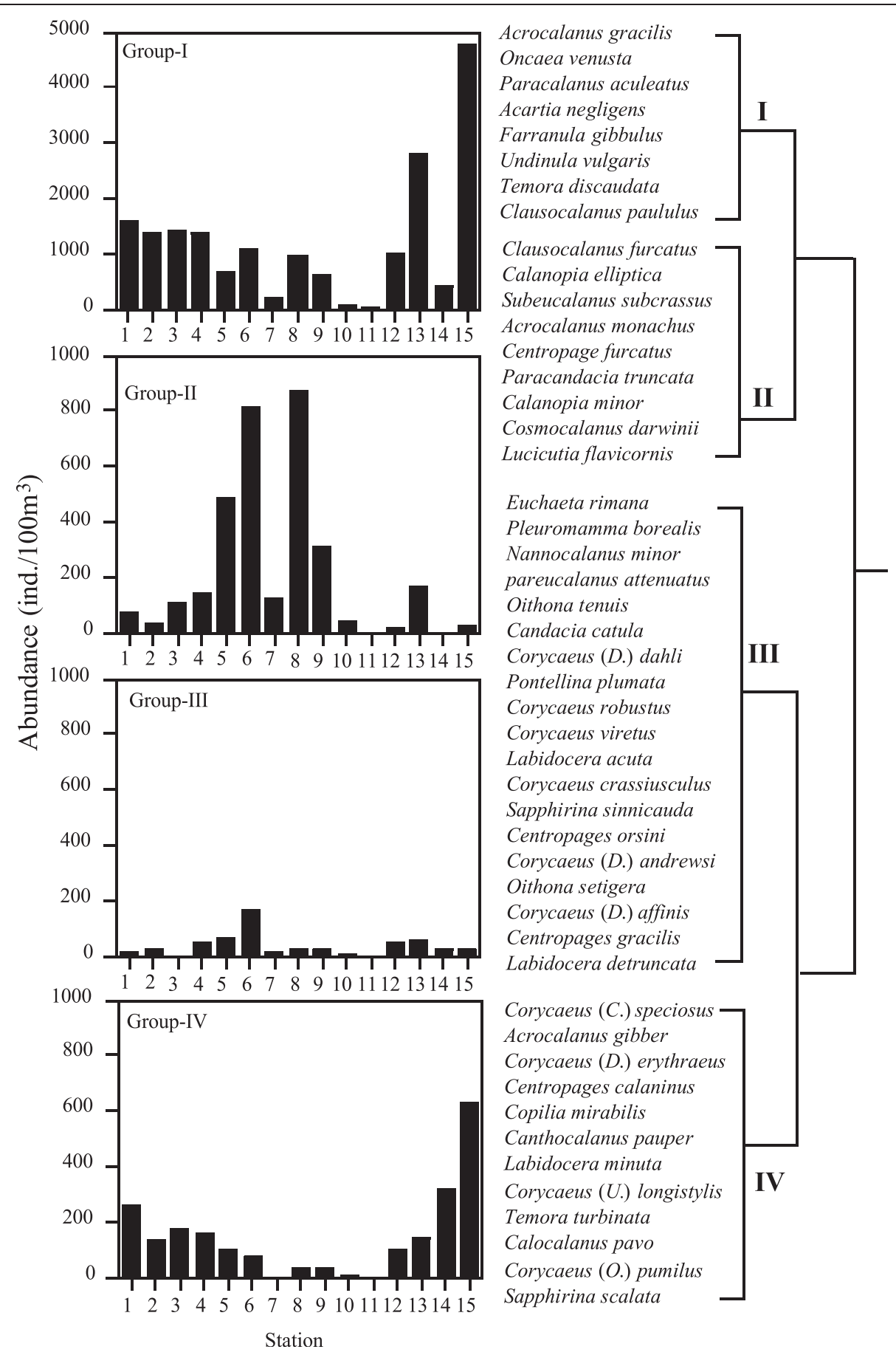

Figure 5 Covarying copepod species groups and their distribution patterns in the waters southwest of Taiwan. During the cruise of 1 to 3 October 1996.

copepods in the Kuroshio edge exchange processes (KEEP) sector of the western North Pacific was estimated as 53 by Tan (1967), 113 by Shih and Chiu (1998), 144 by Hsiao et al. (2004), 174 by Hsiao et al. (2011), and 78 copepod species in the study by Tseng et al. (2008a). Comparing the species list of the present study with that of Shih and Chiu (1998), there are 13 species that are reported in the latter study but are absent from the present study. Surface currents are supposed to have a major impact on the abundance and diversity of planktonic communities in the region studied here (Shih and Chiu 1998).

Some copepod species can be used as indicator species of water masses. Such copepods can provide suitable indicators for water mass movements such as the intrusion 
of Kuroshio Current waters that are otherwise characterized by different temperature and salinities (Hsieh et al. 2004; Hsiao et al. 2004; Hwang et al. 2007; Hsiao et al. 2011). It has to be emphasized that most common copepod species found during the present study do not belong to temperate water species according to the proposed ecological classifications by some researchers (Takahashi and Hirakawa 2001). We suggest here in accordance with previous studies that copepods have been transported from the Kuroshio Current into southwest Taiwan through the Luzon Strait based on similarity analyses (Lo et al. 2004; Hwang et al. 2007). This intrusion has been evidenced by physical data before (Liu et al. 2003). The Kuroshio Current intrusion through the Luzon Strait into the northern South China Sea and southwest Taiwan may also in part explain why copepods show a very high diversity in adjacent waters of the intrusion areas (Hwang et al. 2007).

Similarly, Hwang and Wong (2005) showed that Calanus sinicus is transported by the China Coastal Current along the west coast of Taiwan even as far south as Hong Kong. However, in the present study, $C$. sinicus and Euchaeta concinna, two species with higher index values for winter (see Hwang et al. 2006), originate from the East China Sea (Chen 1992) and were lacking altogether in the present inventory. Under the influence of the SW monsoon, the South China Sea Surface Current moves northwards during summer in the area of the Kuroshio Branch Current (Tseng and Shen 2003). From late autumn to early spring (November to March), the NE monsoon drives water masses from the East China Sea along the China coast line towards the Taiwan Strait, resulting in the obstruction of the northflowing Kuroshio Current at the Changyun Ridge. The Kuroshio Current can flow over the Changyun Ridge and affects the northern part of the Taiwan Strait only when the NE monsoon begins to subside in spring.

Several species were found in comparatively low numbers in the present study. One possible explanation for this could be the unequal distribution of copepods vertically in the water column. A recent study from an upwelling system in the southeastern TS showed that most copepod species stay in deeper waters (Kao 2003). Similarly, a study of copepods in the coral reef ecosystem of Ken-tin, southern Taiwan, demonstrated that several species never migrate to the surface (Lo et al. 2004).

According to the present study, the dominant ten copepod species were similar at all stations considered during the present study. The similarity of dominant copepod species in these regions indicate a long-term water mixing. However, the dominant copepod species in the present study were very different from northern Taiwan (Tseng et al. 2008b,c,d), indicating a separation of northern and southern water masses. Influenced by the SW monsoon, the South China Sea surface current moves northwards during summer to the area of the Kuroshio Branch Current (Tseng and Shen 2003). The zooplankton communities in the boundary waters are unique and diverse as a result of the collective impacts of these three water circulations (Shih and Chiu 1998). According to the present study, it is suggested that sampling stations in the NSCS have higher copepod densities as well as species numbers than those of the KC. Furthermore, lower latitudes show generally higher copepod species richness than higher latitudes, confirming a higher tropical diversity. In terms of the vertical profile of the water column, copepod abundances are generally higher in the upper $50 \mathrm{~m}$ than in deeper strata of the water column. Several species have been suggested to be associated with water masses in that region.

\section{Conclusions}

High copepod abundances in the northeastern South China Sea during summer are caused by both a yearround Kuroshio Current intrusion and the South China Sea surface current driven by the SW monsoon. Both currents bring plankton from subtropical and tropical regions. The stations close to the Kuroshio Current show a higher species diversity $\mathrm{H}^{\prime}$ and a higher species richness. Several indicator species suggest that the study area is highly influenced by water masses from the northern South China Sea as well as from the Kuroshio Current.

\section{Competing interests}

The authors declare that they have no competing interests.

\section{Authors' contributions}

JSH designed the experiment and carried out the zooplankton sampling in South China Sea cruise. WTL analyzed data and made figures and tables. HUD and JSH finalized the manuscript. All authors read and approved the final manuscript.

\section{Acknowledgements}

We thank the members of JS Hwang's laboratory for their assistance in field sampling and the provision of data. Special thanks are dedicated to the Taiwan Ocean Research Institute in providing us with weather information from the data bank for atmospheric research. We thank the captain and crew of Ocean Researcher III, Taiwan. This research was supported by grants from the Ministry of Science and Technology of the ROC to J.S. Hwang (NSC86-2611-M-019-009-OS and NSC102-2611-M-019-003) and to W.T. Lo (NSC96-2611-M-110-006 and 97C030200 (Kuroshio Project)). This study was supported by a NRF Collaboration Project (2012-R1A2A2A02012617).

\section{Author details}

${ }^{1}$ Department of Marine Biotechnology and Resources, National Sun Yat-Sen University, No. 70, Lienhai Road, Kaoshiung 804, Taiwan. ${ }^{2}$ Department of Biomedical Science and Environmental Biology, Kaohsiung Medical University, No. 100, Shin-Chuan 1st Road, Kaohsiung 80708, Taiwan. ${ }^{3}$ Institute of Marine Biology, National Taiwan Ocean University, Keelung 202, Taiwan.

\section{Received: 3 September 2013 Accepted: 4 September 2014}

\section{References}

Bradford-Grieve JM (1994) Pelagic calanoid Copepoda: Megacalanidae, Calanidae, Paracalanidae, Mecynoceridae, Eucalanidae, Spinocalanidae, Clausocalanidae. New Zealand Oceanogr Inst Mem 102:1-160 
Chang W-B, Tseng L-C, Dahms H-U (2010) Abundance, distribution and community structure of planktonic copepods in surface waters of a semi-enclosed embayment of Taiwan during monsoon transition. Zool Stud 49:735-748

Chen QC (1992) Zooplankton of China Seas (1). Science Press, Beijing, p 87

Chen QC, Zhang SZ (1965) The planktonic copepods of the yellow sea and the East China Sea. I. Calanoida. (In Chinese, with English abstract). Stud Mar Sin 7:20-133

Chen QC, Zhang SZ, Zhu CS (1974) On planktonic copepods of the yellow sea and the East China Sea. II. Cyclopoida and Harpacticoida (In Chinese, with English abstract). Stud Mar Sin 9:27-100

Chihara M, Murano M (1997) An illustrated guide to marine plankton in Japan. Tokyo University Press, Tokyo Japan, p 1574

Dahms H-U, Hwang J-S (2010) Natural pollution in the plankton-with a case study from a hydrothermal vent site at Kueishantao. NE-Taiwan J Ocean Underwater Technol 20:50-56

Frost B, Fleminger A (1968) A revision of the genus Clausocalanus (Copepoda: Calanoida) with remarks on distributional patterns in diagnostic characters. Bull Scrip Institut Oceanogr Univ California 12:1-235

Hsiao SH, Lee CY, Shih CT, Hwang JS (2004) Calanoid copepods of the Kuroshio Current east of Taiwan, with notes on the presence of Calanus jashnovi Hulseman, 1994. Zool Stud 43(2):323-331

Hsiao SH, Fang TH, Shih CT, Hwang JS (2011) Effects of the Kuroshio Current on copepod assemblages in Taiwan. Zool Stud 50(4):475-490

Hsieh CH, Chiu TS, Shih CT (2004) Copepod diversity and composition as indicators of intrusion of the Kuroshio Branch Current into the Northern Taiwan Strait in Spring 2000. Zool Stud 43:393-403

Hsieh HY, Lo WT, Wu L (2012) Community structure of larval fishes from the southeastern Taiwan Strait: linked to seasonal monsoon-driven currents. Zool Stud 51:679-691

Hsieh HY, Lo WT, Wu L, Liu DC, Su WC (2011) Comparison of distribution patterns of larval fish assemblages in the Taiwan Strait between the northeasterly and southwesterly monsoons. Zool Stud 50:491-505

Huys R, Boxshall GA (1992) Copepod Evolution. The Ray Society, London

Hwang JS, Chen QC, Wong CK (1998) Taxonomic composition and grazing rates of calanoid copepods in coastal waters of northern Taiwan. Crustaceana 71:378-389

Hwang JS, Wong CK (2005) The China Coastal Current as a driving force for transporting Calanus sinicus (Copepoda: Calanoida) from its population centers to waters of Taiwan and Hong Kong during the winter northeast monsoon period. J Plankton Res 27:205-210

Hwang JS, Souissi S, Tseng LC, Seurong L, Schmitt FG, Fang LS, Peng SH, Wu CW, Hsiao SH, Twan WH, Wei TP, Kumar R, Fang TH, Chen QC, Wong CK (2006) A 5-year study of the influence of the northeast and southwest monsoons on copepod assemblages in the boundary coastal waters between the East China Sea and the Taiwan Strait. J Plankton Res 28:943-958

Hwang JS, Dahms H-U, Tseng LC, Chen QC (2007) Intrusions of the Kuroshio Current in the northern South China Sea affect copepod assemblages of the Luzon Strait. J Exp Mar Biol Ecol 352:12-27

Kao T (2003) Temperospatial distribution and feeding impact of copepods in the Coral Reefs of Ken-Ting, Taiwan, Master Thesis. National Taiwan Ocean University, Taiwan, p 125, in Chinese with English abstract

Liu SH, Sun S, Han BP (2003) Diel vertical migration of zooplankton following optimal food intake under predation. J Plankton Res 25:1069-1077

Lo WT, Hwang JS, Chen QC (2004) Spatial variations of copepods in the surface waters of the southeastern Taiwan Strait. Zool Stud 43:218-228

Markhaseva EL (1996) Calanoid copepods of the family Aetideidae of the world ocean. Trud Zool Instit Russian Acad Sci 268:1-331

Nishida S (1985) Taxonomy and distribution of the family Oithonidae (Copepoda, Cyclopoida) in the Pacific and Indian Oceans. Bull Ocean Res Inst Univ Tokyo 20:1-167

Shih CT, Chiu TS (1998) Copepod diversity in the water masses of the southern East China Sea north of Taiwan. J Mar Syst 15:533-542

Shih CT, Young SS (1995) A checklist of free-living copepods, including those associated with invertebrates, reported from the adjacent seas of Taiwan. Acta Zool Taiwan 6:65-81

Takahashi T, Hirakawa K (2001) Day-night vertical distributions of the winter and spring copepod assemblages in Toyama Bay, southern Japan Sea, with special reference to Metridia pacifica and Oithona atlantica. Bull Plankton Soc Jap 48:1-13

Tan TH (1967) On distributions of copepods in the surrounding waters of Taiwan. Rep Inst Fishery Biol Minist Econ Aff National Taiwan Univ 2:14-20
Tseng LC, Dahms H-U, Chen QC, Hwang JS (2008a) Copepod assemblages of the northern South China Sea. Crustaceana 81:1-22

Tseng LC, Kumar R, Dahms H-U, Chen CT, Chen QC, Hwang JS (2008b) Epipelagic mesozooplankton succession and community structure above a marine outfall in the northeastern South China Sea. Environ Biol 29:275-280

Tseng LC, Kumar R, Dahms H-U, Chen CT, Souissi S, Chen QC, Hwang JS (2008c) Copepod community structure over a marine outfall area in the northeastern South China Sea. J Mar Biol Assoc UK 88:955-966

Tseng LC, Souissi S, Dahms H-U, Chen QC, Hwang JS (2008d) Copepod communities related to water masses in the southwest East China Sea. Helgol Mar Res 62:153-165

Tseng RS, Shen YT (2003) Lagrangian observations of surface flow patterns in the vicinity of Taiwan. Deep-Sea Res II 50:1107-1116

doi:10.1186/s40555-014-0066-7

Cite this article as: Lo et al:: Water mass transport through the northern

Bashi Channel in the northeastern South China Sea affects copepod assemblages of the Luzon Strait. Zoological Studies 2014 53:66.

\section{Submit your manuscript to a SpringerOpen ${ }^{\circ}$ journal and benefit from:}

- Convenient online submission

- Rigorous peer review

- Immediate publication on acceptance

- Open access: articles freely available online

- High visibility within the field

- Retaining the copyright to your article

Submit your next manuscript at $>$ springeropen.com 